\title{
AS RELAÇÕES ENTRE IMAGEM E ARQUITETURA: UM OLHAR SOBRE A CATEDRAL DIOCESANA DE SANTA MARIA, MÃE DE DEUS, CASTANHAL (PA)
}

\author{
Marcos Murelle Azevedo Cruz ${ }^{1}$ \\ Daniel S. Fernandes ${ }^{2}$
}

\begin{abstract}
RESUMO
O objetivo deste trabalho é apresentar a relação entre imagem e arquitetura contemporânea nas expressões da Catedral Diocesana de Santa Maria, Mãe de Deus, em Castanhal (PA). Sendo uma construção recente, este tempo católico de rito romano protagoniza o encontro de diversas culturas e tradições religiosas do catolicismo entre Ocidente e Oriente que se expressam numa estrutura versada em vitrais, mosaicos, campanários, símbolos litúrgicos e mobiliários com entalhamentos de imagens em mármore branco e bronze. É possível que um acurado estudo sobre as expressões materiais e espirituais deste templo cristão aponte para um paradoxal encontro entre o desencantamento da arquitetura e o retorno ao simbolismo das imagens, tão caro à evangelização nos dias atuais.
\end{abstract}

Palavras-chave: Arquitetura. Catedral. Imagem.

\begin{abstract}
The objective of this work is to present the relationship between image and contemporary architecture in the expressions of the Diocesan Cathedral of Santa Maria, Mother of God, in Castanhal (PA). Being a recent construction, this Roman time of Roman rite stars the encounter of diverse cultures and religious traditions of the catholicism between West and East that express in a structure versed in stained glass, mosaics, bell towers, liturgical symbols and furniture with carvings of images in white marble and bronze. It is possible that an accurate study of the material and spiritual expressions of this Christian temple points to a paradoxical encounter between the disenchantment of architecture and the return to the symbolism of images so dear to evangelization today.
\end{abstract}

Keywords: Architecture. Cathedral. Image.

\section{APRESENTAÇÃO}

A Catedral Diocesana de Santa Maria, Mãe de Deus, é uma construção contemporânea. O lançamento de sua pedra fundamental ocorreu no dia 24 de Abril de 2001, numa celebração solene presidida pelo então Arcebispo de Belém, D. Vicente Joaquim Zico, que contou com a presença de autoridades civis e militares e uma parcela significativa da população de Castanhal. Foi construída para marcar a presença da Igreja Católica no nordeste paraense, por meio da criação da Diocese de Castanhal, que foi instituída solenemente pelo

\footnotetext{
${ }^{1}$ Mestre em Linguagens e Saberes na Amazônia da Universidade Federal do Pará (UFPA) - Campus de Bragança/PA. Email: marcosmurelle@gmail.com

${ }^{2}$ Doutor em Ciências Sociais/Antropologia. Professor do Programa de Pós-Graduação em Linguagens e Saberes na Amazônia (PPLSA) da Universidade Federal do Pará (UFPA) - Campus de Bragança/PA. Email: dasafe@msn.com
} 
Papa João Paulo II, no dia 29 de Dezembro de 2004, nomeando como seu primeiro bispo diocesano D. Carlos Angelo Verzeletti, empossado no dia 27 de Fevereiro de 2005.

Figura 1: mapa de localização da cidade de Castanhal (PA)

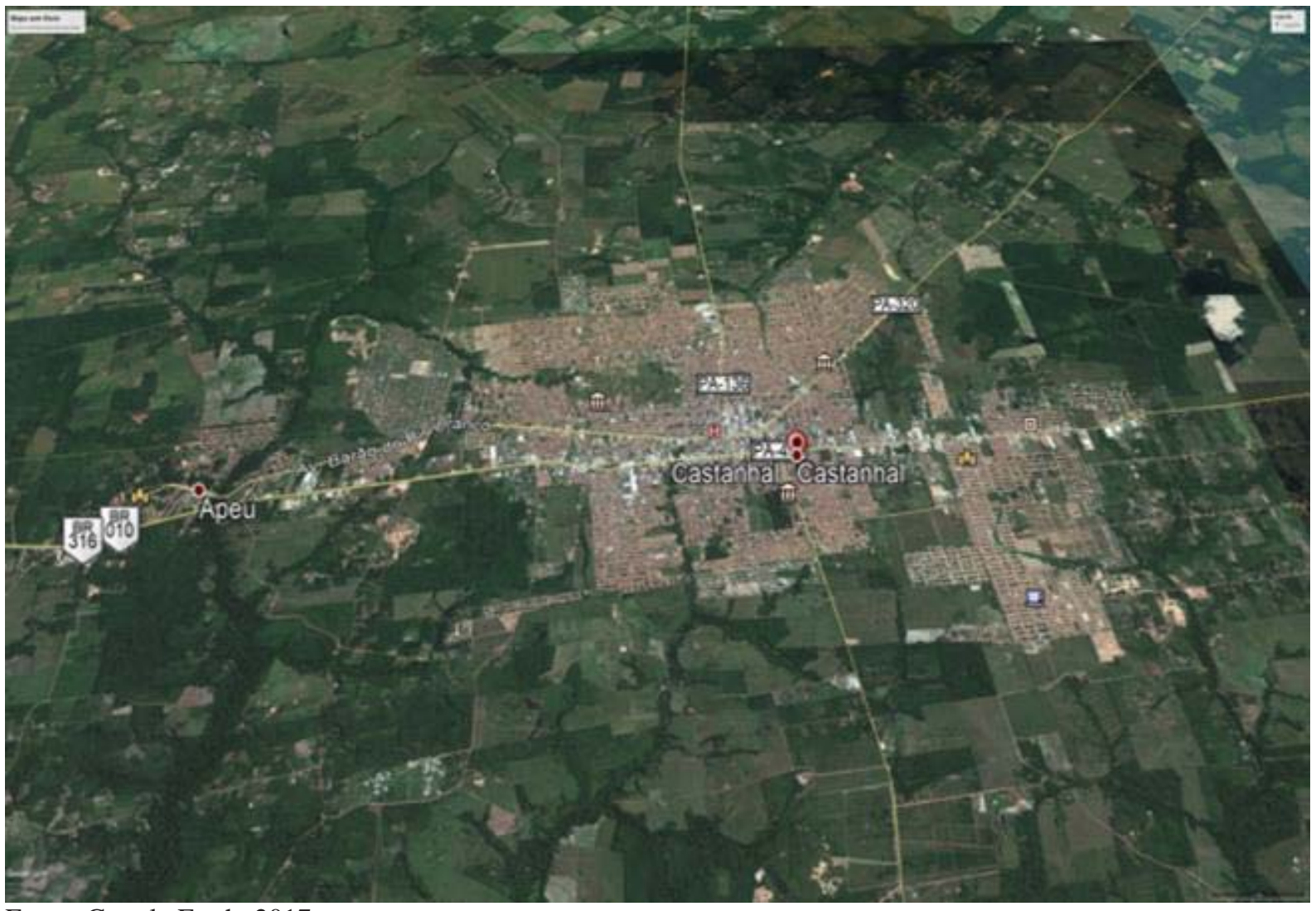

Fonte: Google Earth, 2017

Situada um pouco mais de $75 \mathrm{~km}$ da capital paraense, esta Catedral é um dos templos mais importantes da diocese, não somente por ser a expressão do poder da igreja católica sobre o território, mas por seu valor material, simbólico e espiritual, que caracteriza a unidade entre a igreja local por meio de seu bispo diocesano e os seus fiéis que estão presentes em toda a extensão do território, seja da cidade, seja de uma parte do nordeste paraense. Além do mais, esta arquitetura está associada à ideia de lugar onde está "cadeira" do bispo, daí o sentido de "cátedra" que segundo a tradição cristã, evoca o poder régio do autêntico sucessor dos apóstolos que recebeu a incumbência de orientar, sob a guia do Espírito Santo, o rebanho a ele confiado.

Este templo é também percebido como uma prefiguração da casa do Senhor, como ensina a tradição bíblica, que ao recordar as palavras do próprio Jesus citando o profeta Isaías $(56,7)$ afirmou: "minha casa será casa de oração para todos os povos" (Mt 21,13); quando anunciou a destruição do templo de Jerusalém e a construção de outro templo, não mais feito 
por mãos humanas como relata o livro de Marcos $(14,58)$. Com isso, o próprio Jesus se referia ao seu corpo que ressuscitaria no terceiro dia, após a sua morte, e mais especificamente, ao seu corpo místico, que é a Igreja. Para além do seu caráter espiritual, esta grande igreja concentra organismos que articulam ações pastorais em toda a diocese, cuja finalidade é garantir a unidade das ações pastorais entre hierarquia eclesiástica e o povo de Deus ${ }^{3}$.

Os fiéis admiram-se desta arquitetura não somente pelo seu sentido espiritual, mas pelo seu grande valor artístico. Neste espaço são articuladas produções de sentidos entre os artefatos e os espaços celebrativos, e destes com as imagens em mosaico talhadas na parede absidal do templo que, por sua vez, são um registro de tudo aquilo que ocorre no altar. Por conseguinte, os símbolos litúrgicos que ladeiam o presbitério são igualmente registros da presença de uma cultura material tipicamente católica, compilada na escrita e decodificada no exercício de interpretação de gestos e rituais.

Possuindo uma estrutura física formada por paredes de "pedras vivas" que simbolizam a "Mão de Deus", o desenho arquitetônico desta igreja inaugura uma forma diferenciada de percepção do espaço sagrado, cujo paradoxo está justamente no encontro de perspectivas artísticas do passado e do presente. Se por um lado, se apresenta com tendências associadas à época em que foi erguida, por outro lado guarda traços de uma edificação que remonta a uma antiga tradição dos cristãos do primeiro milênio segundo a qual o teto e as paredes das igrejas não eram feitos apenas para proteger da chuva e do sol, mas para atualizar aquilo que era celebrado. Por conseguinte, a casa dos cristãos era projetada de acordo com a estrutura das igrejas de modo que aquilo que se realizava no templo estendia-se para o interior das casas.

\section{A RELAÇÃO ENTRE IMAGEM E ARQUITETURA NO CONTEXTO CRISTÃO}

A catedral é a casa do bispo, e esta denominação está associada a uma dimensão temporal e sacralizada, como se observa já nos séculos XII e XIII, especialmente na França, quando os reinados estavam associados ao poder da Igreja, cujas formas de governo possuíam dimensões espiritual e temporal. Seguindo esta tendência, a construção de edifícios cristãos e o entalhamento de imagens apresentavam o poder desta relação. Por outro lado, ao se referir à grandeza das catedrais góticas, Fulcanelli (1964, p. 45) mostra estruturas não apenas para cultuar o cristianismo, mas "uma vasta condenação de idéias, de tendências, de fé populares,

\footnotetext{
${ }^{3}$ Uma categoria de análise teológica amplamente discutida no catolicismo que caracteriza a unidade da fé que os fiéis professam em unidade da fé católica.
} 
um todo perfeito ao qual nos podemos referir sem receio desde que se trate de penetrar o pensamento dos ancestrais, seja qual for o domínio: religioso, laico, filosófico ou social.”

Partindo destas percepções de espaços onde se encontram o sagrado e o profano, formuladas no interior de tradições artísticas e religiosas de uma época, refiro-me aos estudos realizados por Duby (1979); Fulcanelli (1964) e Christian Jacq \& François Brunier (1974) para apresentar a estreita relação entre arquitetura e imagem, de como estes elementos artísticos e arquitetônicos estruturavam a produção de sentidos, revelando expressões de beleza, concepções de mundo e experiências religiosas, a partir do encontro entre arte e pensamento.

Pois bem, os estudos realizados por Duby (1979, p. 101) mostram que a catedral surge como expressão visível do poder de reis e de bispos, pois nestas figuras o "sagrado se liga intimamente ao profano, e se opera uma junção miraculosa entre o temporal e o intemporal". Mas não somente. A construção das catedrais está também associada ao ressurgimento das cidades e da riqueza obtida da intensa produção agrícola dos campos, do fluxo de bens e do comércio provenientes das lavouras, o que levou muitos senhores a estabelecer residência nas cidades restauradas. Este período foi seguido por um intenso processo de sacralização da vida social, não obstante as tensões entre o desejo de vida feliz pelo usufruto das riquezas, e o surgimento dos fins práticos do discurso da pobreza como caminho para a perfeição cristã.

Neste contexto de desenvolvimento, observa-se o aparecimento de bispos construtores que se empenharam na construção desses templos angariando, para isto, recursos abundantes por meio de cobranças abusivas de impostos em desfavor dos grupos que compunham a sociedade medieval como o clero, a cavalaria e a massa dos pobres, esta última, reconhecidamente explorada. No cenário de tensões e cobranças, o grupo da cavalaria é a principal expressão de combate às formas abusivas de taxação de impostos, que eram direcionadas para a construção destas igrejas. Paradoxalmente, é nesse contexto de tensões que a arte nascente das catedrais surge como expressão de contradição ao moralismo da igreja, e se coloca contra toda forma de negação da vida e do desejo de liberdade. Por outro lado, as imagens apresentam perspectivas que agregam concepções de sagrado e de profano, mesmo que este compartilhamento de concepções no espaço de finalidades inicialmente predeterminadas de uma igreja catedral, com um tempo, tenha sido esquecido.

Em todo o caso, na arquitetura de algumas destas igrejas figuram imagens do cotidiano, que revela o antagonismo latente entre a igreja e a sociedade feudal: o que parece indicar que naquele momento as imagens talhadas retratavam os momentos vividos no trabalho nestas lavouras e nas cidades. Enquanto isso, a preponderância das imagens do que 
simbolizava o encontro entre a monarquia e o clericalismo, associada ao mistério divino na unidade do poder temporal, as imagens talhadas na arquitetura das catedrais celebram a glória dos reinados e o poder régio de Cristo e da Virgem Maria. O fato é que este contexto de associações evidencia uma estreita relação entre o surgimento das imagens artísticas e as estruturas das relações sociais, e o pensamento social de uma época.

Por outro lado, ao apresentar o sentido da arte gótica das catedrais francesas no período medieval, Fulcanelli (1964) mostra que a estrutura destes templos apresentam formas arquitetônicas que não eram feitas somente para adorar o poder régio de Cristo e da Virgem Maria, mas apresentavam em seus arcos, portas e imagens um conjunto de ideias, crenças e concepções de mundo que figuravam como registro e perpetuação de um pensamento social de uma determinada época. O traço marcante destas construções é a "transgressão de finalidade" segundo a qual uma catedral não deve apenas garantir a primazia do culto divino, mas revelar a dimensão profana das sensações, dos sentidos vividos na experiência do sagrado, sem ocultismos. Assim, um templo deve servir a outras circunstâncias, e mesmo que a beleza dos vitrais e o silêncio envolvente convide a oração, sempre existirá a presença de um paradoxo entre a finalidade estabelecida e o devir da experiência religiosa. Para Fulcanelli (1964, p. 46) estes momentos expressavam a importância de a experiência religiosa “descobrir-se, além da inspiração ardente nascida de uma fé robusta, as mil preocupações da grande alma popular, a afirmação da sua consciência, e a sua vontade própria, a imagem do seu pensamento no que ela tem de complexo, de abstrato, de essencial, de soberano".

O autor mostra, com raríssimas exceções, que desde sempre o plano dos edifícios das igrejas medievais foram construídas em forma de cruz latina, no chão. Pois como se sabe, a palavra "cruz" vem do hieróglifo alquímico do crisol, que os latinos chamavam de cricibulum que vem da raiz crux e crucis. Desse modo, o costume de construir igrejas em forma de cruz evocava um simbolismo de associações entre a paixão e o sofrimento de Cristo na cruz com a vida humana, marcada por toda sorte de precariedades, e o intuito era apresentar o sentido redentor do sofrimento, pela experiência da fé. Notoriamente, a palavra cruz não é um elemento estritamente cristão, pois o seu simbolismo estabelece uma correlação com elementos de outras culturas, credos e confissões religiosas. Estas formas arquitetônicas com suas iconografias colocam a questão: o que esta e outras imagens poderiam nos transmitir?

Para Christian Jacq \& François Brunier (1974) estas construções religiosas guardam não somente uma arte litúrgica de beleza incomensurável, mas um conjunto de mensagens, isto é, aquilo que os construtores, guiados por uma "intuição" artística e espiritual, gostariam de dizer, por meio das imagens. Todavia, o estudo transdisciplinar das construções religiosas, 
põe em questão a forma como este tema é tratado, recolocando algumas expressões de mentalidade contemporânea segundo a qual o estudo das construções religiosas medievais é tido como algo do passado. Com efeito, o estudo da relação entre arquitetura e imagem tem redescoberto valores fundamentais no entendimento dos sentidos guardados por estas construções. Assim, ao estudar os elementos estéticos e narrativos dos templos, há que se considerar a mensagem oculta nestas imagens, que se atualiza pelo gesto pervivente das obras. Portanto, a arte que se impunha nos planos de construção de edifícios cristãos e as concepções de imagens que se tinha, estavam muito associados às concepções imaginativas que as sociedades medievais tinham sobre o sagrado, a experiência cotidiana da vida, percepções estas que serão recolocadas com o surgimento do modernismo e pós-modernismo na arte.

Em todo o caso, os estudos realizados por Artola (1998) mostram como a relação entre arte e cristianismo tornou possivel à feitura de imagens profundamente associadas à imanência e transcendência, em que a criação e a imaginação, não estavam necessariamente associadas à ordem do culto para o cristianismo, mas à conveniência. De igual modo, as figurações da arte cristã como o ícone, se constituíram por necessidade de ordem catequética, como canal de produção de sentidos, sendo conhecida como arte eminentemente litúrgica. Desta feita, existe uma orientação pastoral que associa a interpretação destas imagens à relação entre contemplação e a evangelização. Nesse sentido, o autor mostra que, para fazer uma autentica história da arte cristã é necessário antes de tudo, acessar a intencionalidade artística daqueles que criaram as imagens, e o espírito da época em que elas foram criadas.

Portanto, ao tratar sobre o nascimento da arquitetura e da iconografia cristã, é necessário ter em conta os componentes fundamentais que orientam seus processos de interpretação tomados respectivamente em seus elementos filosóficos como arte e transcendência; em sua dimensão histórica nas origens da arte cristã; em seu caráter teológico, tendo em estima a razão de ser da arte cristã; a localização geográfica do pensamento cristão entre Ocidente e Oriente em suas especificidades; e por fim, levando em conta as formas como é tratado o patrimônio material e imaterial na sua relação com a sociedade contemporânea, cuja dimensão está inevitavelmente associada ao pós-modernismo, na arte.

Com efeito, os estudos de Fredric Jameson (1984) indicam que a partir do pósmodernismo, ocorre um processo de pulverização das concepções do sentido de história não metafórica, essa dimensão replicada pelas expressões artísticas vigentes, provocando o esvaziamento do sentido da história, da tradição, fenômenos que são associados ao sentimento de fim da história, fim da arte, fim das classes, etc. Nesse contexto, a arquitetura é a dimensão que mais incorpora elementos de desencantamento da cidade, seguido por uma profunda 
rediscussão sobre o legado artístico e cultural das épocas anteriores. Portanto, o pósmodernismo é, pois, o anuncio de mudanças em padrões culturais em que se observam "rupturas", isto é, o abandono de narrativas lineares e a recusa de certas concepções de representação e simbolismo. É ainda, uma lógica cultural, que estrutura modos de percepções sobre as expressões do mundo da vida, da arte, sendo inevitável que suas concepções estéticas não compartilhem desta tendência, mesmo em se tratando de suas estruturas arquitetônicas.

Nesse aspecto, existe um alinhamento na critica entre arquitetura e conjuntura, que problematiza concepções de urbanismo e estética que até então orientavam o espaço geográfico das cidades. Essas mudanças se fizeram sentir seja pela destruição de elementos estéticos e narrativos que enalteciam a coerência da cidade com os seus bairros, seja pela desarticulação harmônica desses edifícios arquitetônicos. Esses fenômenos contribuíram de na redefinição das relações sociais no espaço das cidades antigas e os bairros. Assim, para Jameson (1984) a arquitetura pós-moderna se estrutura em torno das novas configurações da vida social, e do rompimento de fronteiras internacionais sobre as concepções de arquitetura. Deste modo, a arquitetura acompanha um profundo processo de desencantamento pela cidade, onde se verifica uma tendência que se orienta ou para a apologia ou para estigmatização.

No âmbito da religião, especificamente no caso de uma igreja catedral pós-moderna, existe uma forte tendência à apologia ao poder eclesial sobre o território, em que imagens e inscrições restauram o mito do eterno retorno, de um apelo incessante ao reencontro com a beleza perdida e o simbolismo inaudito, ao mesmo tempo em que compartilham de elementos estéticos do pós-modernismo entre o passado e o presente. Essa faceta da arquitetura preconiza, portanto, um convite ao reencantamento da vida e da experiência religiosa como imanência e como transcendência nas relações sociais, mesmo sob as condições de um mundo que não é mais uma cristandade.

$\mathrm{Na}$ atualidade, as catedrais, em sua maioria, são construídas não mais sob a forma de uma cruz latina. A construção dessas edificações se dá por meio de relações colaborativas de doações em dinheiro de instituições nacionais e internacionais, e seus sentidos simbólico, espiritual e material estão associados ao processo de evangelização e a demarcação simbólica de território. Há muito tempo estes espaços deixaram de possuir uma finalidade estritamente do culto, pois abrigam momentos de mudanças, congressos, reuniões pastorais, situações que revelam outras circunstâncias, que não necessariamente a ação litúrgica. 


\section{A CATEDRAL DE SANTA MARIA, MÃE DE DEUS E O SIMBOLISMO DAS IMAGENS}

\subsection{A PORTA ESTREITA}

O primeiro registro do simbolismo das imagens é a grande porta estreita (fig. 2) que possui aproximadamente 10 metros de comprimento, talhada em peça única, de bronze, que está situada no átrio central da Catedral Diocesana. Por conseguinte, nesta porta está gravada a imagem do Bom Pastor, conforme a descrição da narrativa bíblica de João (10, 1-11). Ela é aberta em celebrações jubilares e festas litúrgicas solenes, no ano santo da misericórdia, etc.

Um agente de pastoral relata que este texto extraído do Novo Testamento, particularmente nos evangelhos e que inspirou a construção desta porta, mostra que as figurações do Bom Pastor reaparecem associadas à figura de Cristo e à sua missão como o pastor do novo Israel. Assim, a porta "estreita" tem como objetivo apresentar que o caminho da salvação pessoal passa pelo sacrifício de si, pela conversão diária do coração e pela tomada de propósitos de mudança de vida, nem sempre aceitável, pois exige sacrifícios pessoais.

Acompanhei os fiéis católicos passando por esta porta nas grandes festas litúrgicas, em especial no ano santo jubilar instituído pelo Papa Francisco. Na ocasião, afirmaram sentir uma energia extraordinária. Um sacerdote católico de idade avançada que acompanhava os fiéis disse sentir uma sensação inexplicável ao passar por esta porta, sente que sua fé se renova.

As imagens entalhadas na porta mostra a ovelha nos ombros do pastor e evoca o texto bíblico: "Eis que o pastor deixou as 99 ovelhas e foi em busca daquela que havia se perdido pelo caminho" como relata Lc (15, 3-7). Lembra o caráter messiânico da vinda de Cristo ao mundo que é guiar e apascentar as ovelhas para que nenhuma delas se perca.

A figura 3 é associada às pessoas, que por sua vez, se reconhecem nessa imagem como "ovelhas" do aprisco do Senhor que reconhecem em Jesus os traços de um Deus misericordioso que acolhe, perdoa cura das feridas e não quer que ninguém se perca. Esta mensagem se torna presente principalmente nas celebrações litúrgicas no gesto devoto da comunhão eucarística. A imagem das ovelhas aos pés do pastor retrata a disposição da escuta de todo cristão, como o próprio Jesus disse: "elas me conhecem e ouvem a minha voz". O elemento que se sobressai nesta narrativa é a comunhão, em que o rebanho reunido aos pés do pastor eterno, permanece unido quando escuta e medita a sua palavra nos diversos momentos da vida. 
Figura 2: Porta de bronze no átrio central da Catedral, com a imagem do Pastor das ovelhas

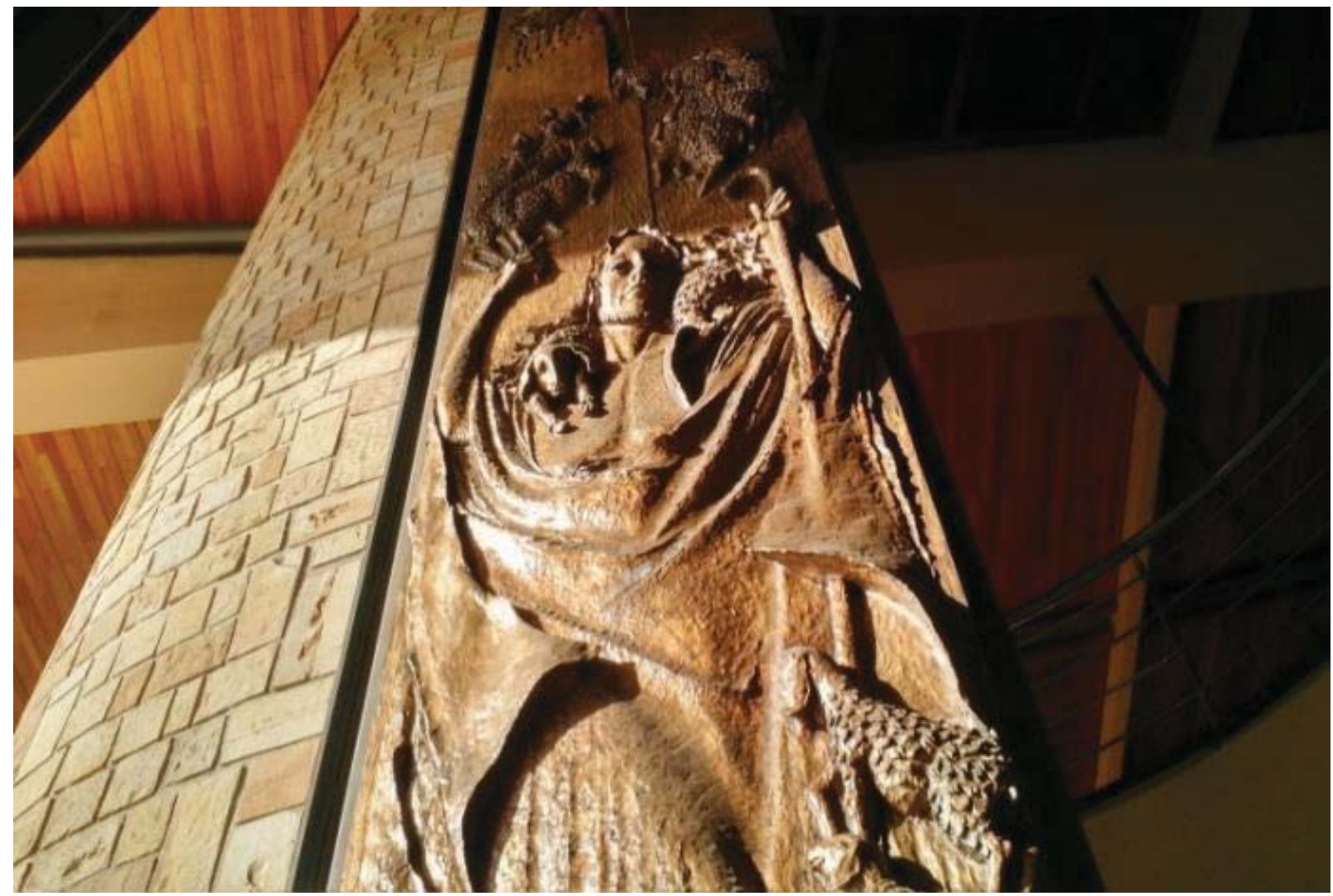

Fonte: Diocese de Castanhal, 2016

Figura 3: Porta de bronze com a imagem das ovelhas

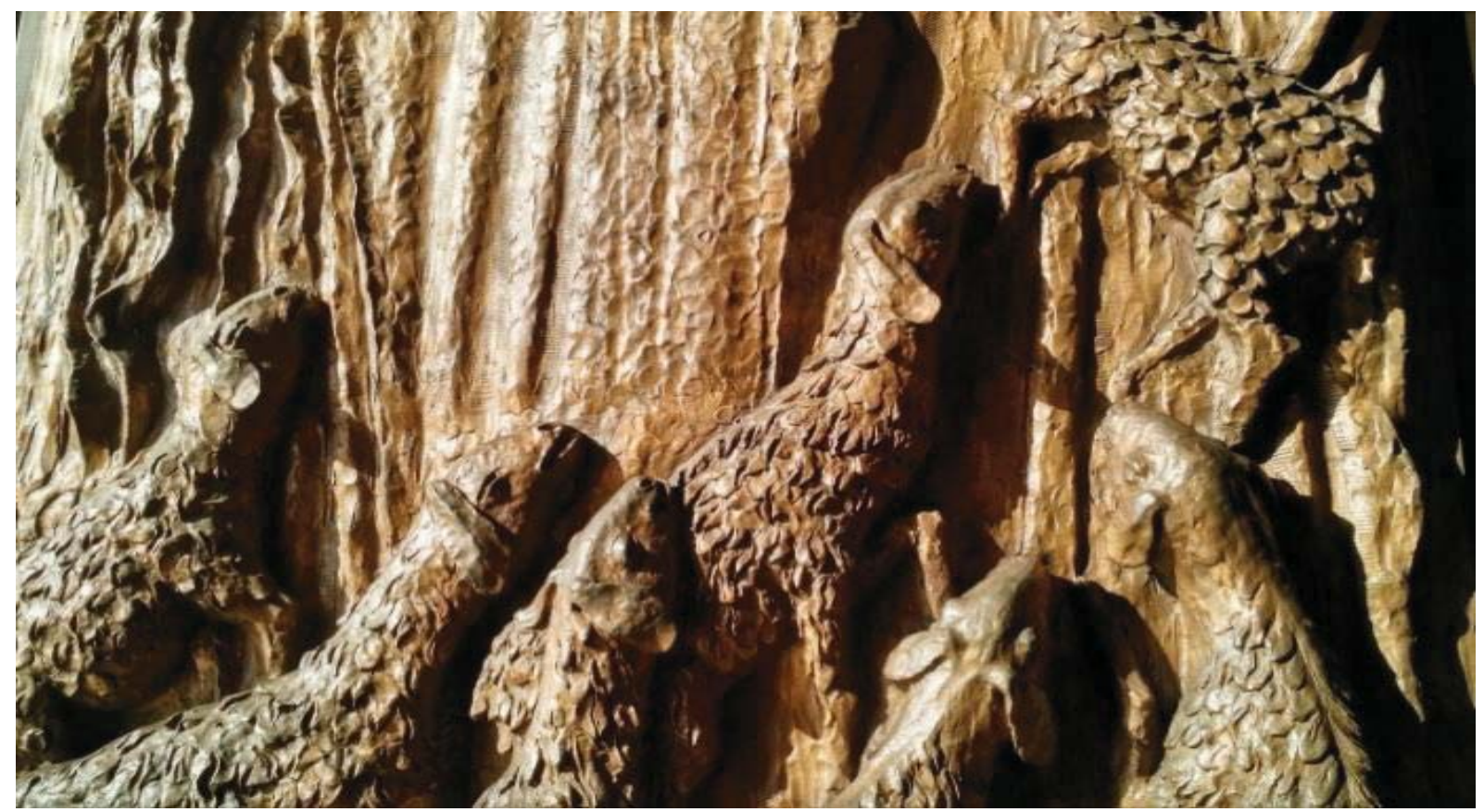

Fonte: Diocese de Castanhal, 2016 


\subsection{O SIMBOLISMO DA PROMESSA}

As imagens a seguir compilam o simbolismo da promessa que Deus fez ao seu povo, por meio dos patriarcas e profetas do antigo testamento, a respeito da vinda do Messias. Elas retomam a passagem do profeta Isaias segundo a qual: "um ramo sairá do tronco de Jessé, um rebento brotará de suas raízes. Sobre ele repousará o espirito do Senhor" (Isaías 11, 1-2). Esta profecia anuncia a vinda do Messias, de origem davídica.

Ao centro da letra M, a imagem da rama, nascida do tronco de Jessé. As iniciais A e M simbolizam a saudação do Anjo Gabriel à Virgem Maria, como narra o livro dos evangelhos. Cf. Lucas $(1,28)$ : “Ave, ó cheia de graça!” (figura 4).

A segunda imagem apresenta o "rebento da raiz de Jessé" que faz menção ao oráculo do profeta, segundo o qual o Messias viria da descendência de Davi (figura 5).

$\mathrm{Na}$ terceira imagem, é apresentado o tronco de Jessé, "da rama nasceu a flor.” O profeta faz uma menção direta a Maria, que gerou na carne, o messias esperado (figura 6).

$\mathrm{Na}$ quarta imagem, a estrela representa as doze tribos de Israel, ou seja, o povo com quem Deus fez aliança, em primeiro lugar. O simbolismo das 12 estrelas reconstitui a imagem do templo como morada de Deus cujo sacerdote é o Cristo, que pela sua morte e ressurreição, leva a perfeição à antiga e nova aliança, realizada por Deus com o novo Israel (figura 7).

Figura 4: O tronco de Jessé (1/3) De Jessé nasceu a rama

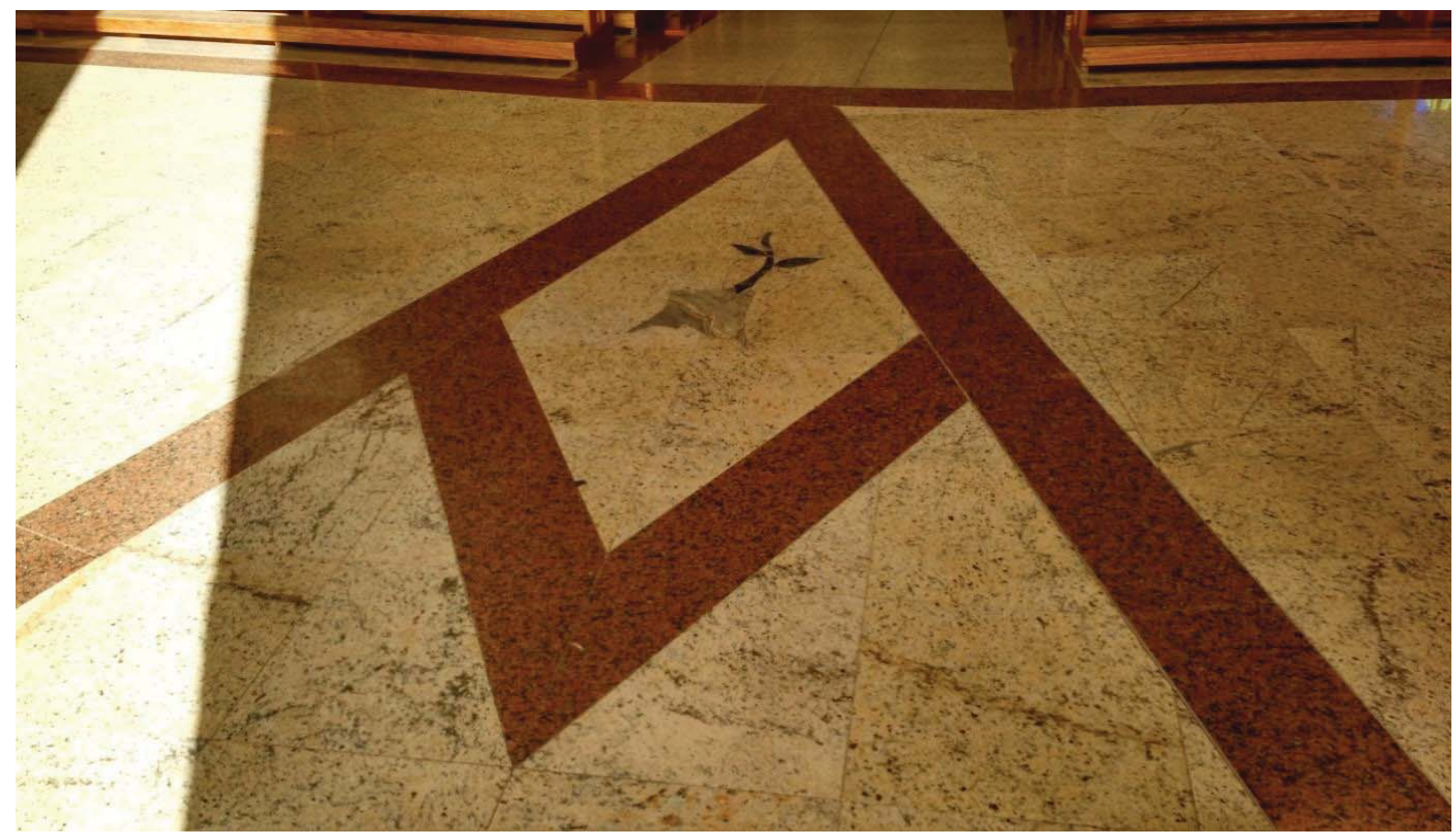

Fonte: Diocese de Castanhal (2016) 
Figura 5: O rebento da raiz de Jessé (2/3) Da rama nasceu a flor

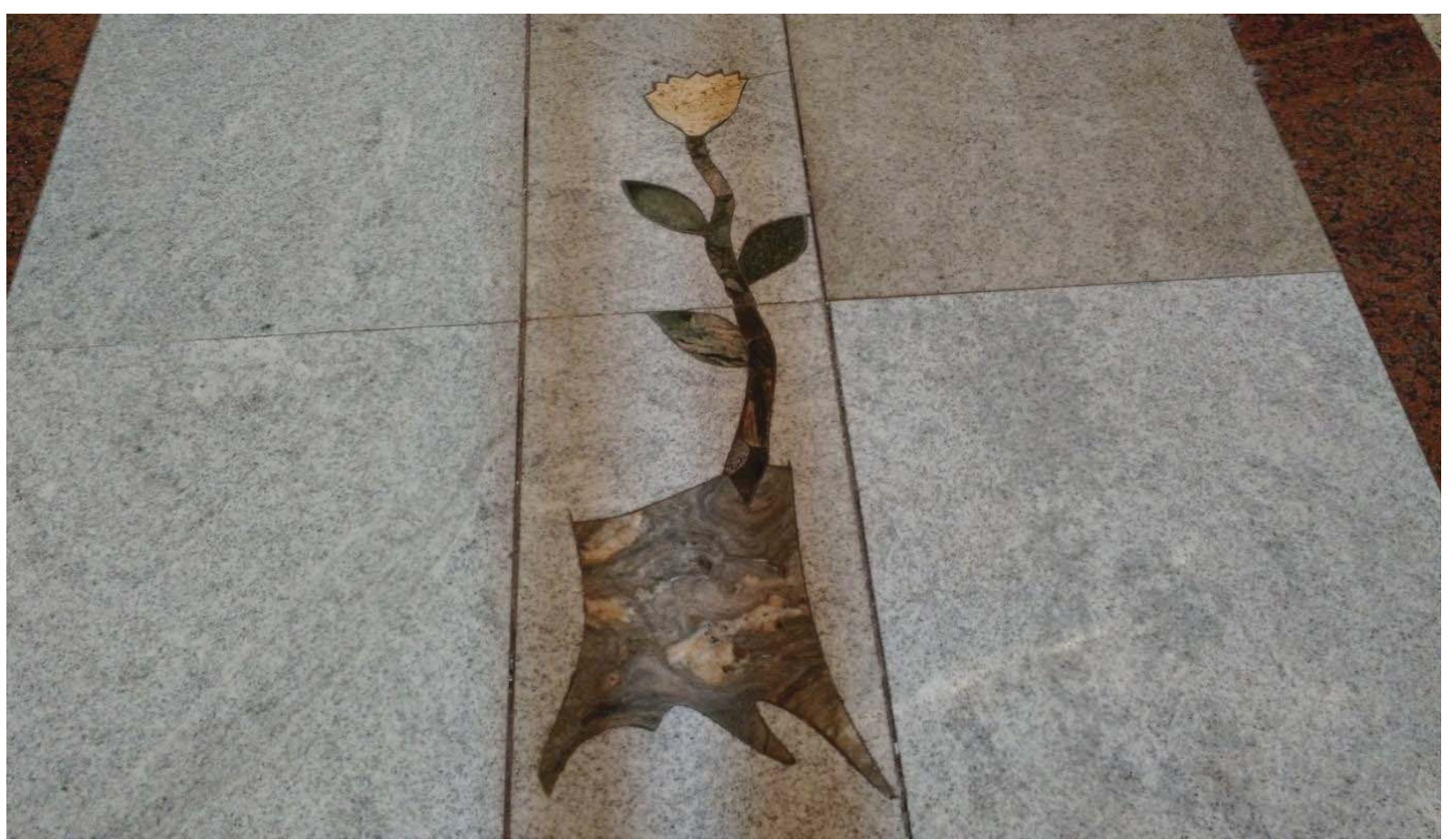

Fonte: Diocese de Castanhal (2016)

Figura 6: O Tronco de Jessé (3/3) Da flor nasceu Maria

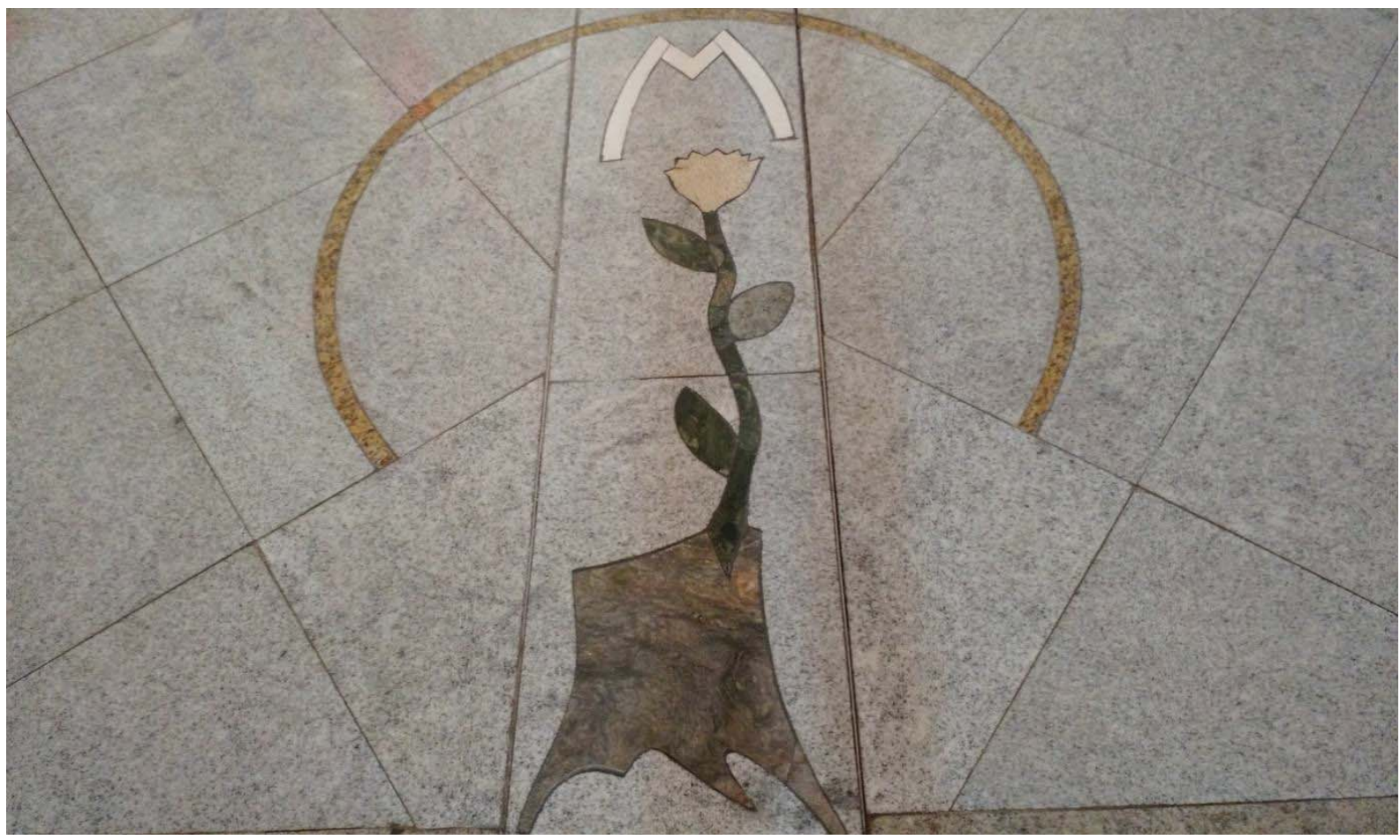

Fonte: Diocese de Castanhal, 2016 
Figura 7: As doze tribos de Israel Doze estrelas são desenhadas no chão da Catedral

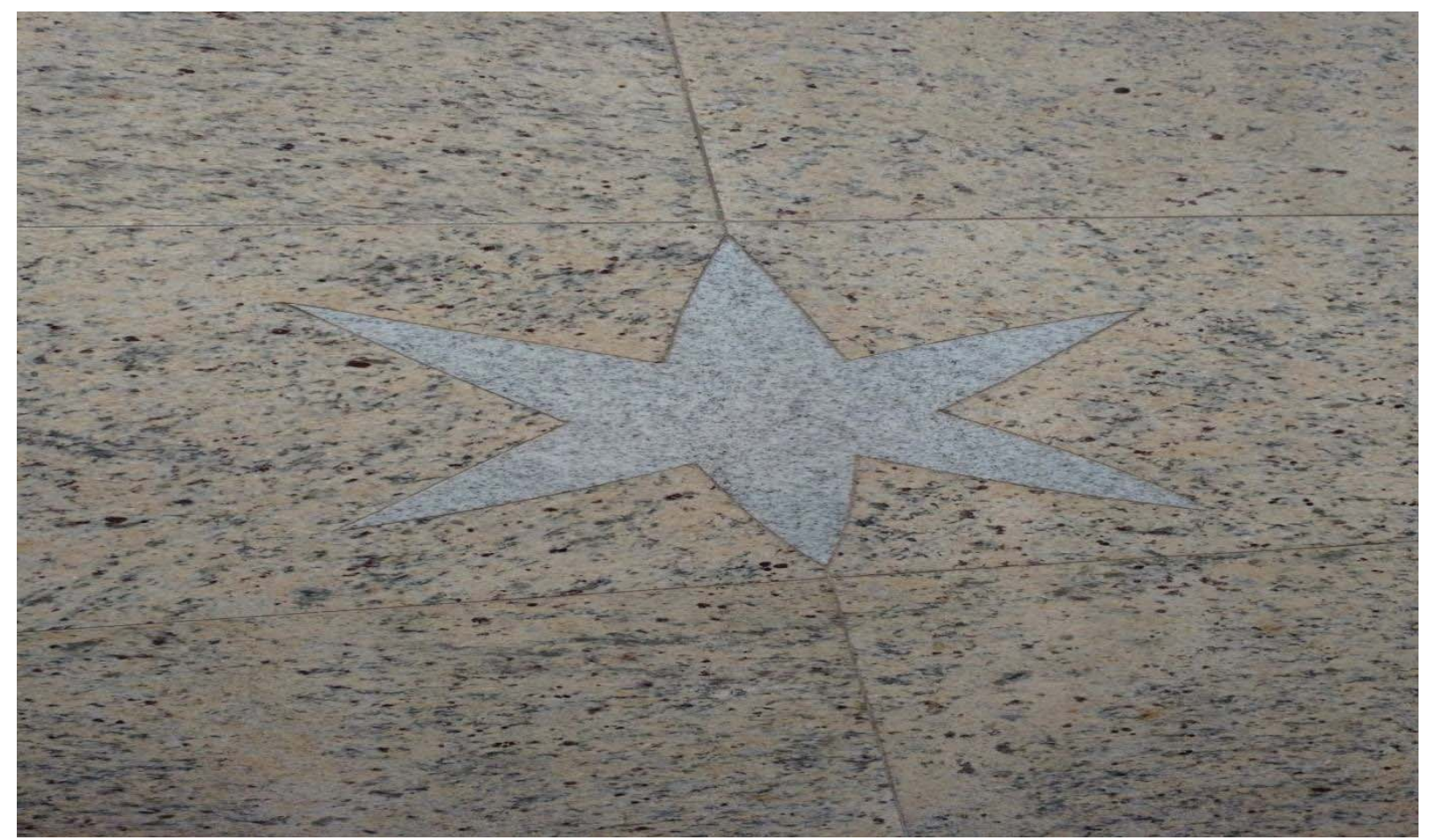

Fonte: Diocese de Castanhal, 2016

\subsection{O CULTO DIVINO E A INTERAGENCIA DAS IMAGENS}

Os intelectuais da comunidade apresentam o aspecto celebrativo das representações dos espaços e dos símbolos litúrgicos, a começar do presbitério ${ }^{4}$, os elementos que traduzem o mistério celebrado. Estas expressões materiais são exteriorizações que caracterizam o espaço da liturgia católica em seus diferentes momentos e manifestam uma dimensão ritualizada da vida. São manifestações de uma cultura material do catolicismo romanizado, e seus símbolos intermediam momentos diferentes nas cerimônias que ocorrem no interior da catedral.

O altar é o local por excelência onde se estrutura uma hierarquia de lugares e funções dentro da celebração, o espaço "onde se celebra a missa e se proclama a Palavra de Deus" ensina o mestre de celebrações. Os sujeitos desenvolvem atribuições de acordo com o seu múnus ${ }^{5}$ que lhes é conferido no batismo. Assim, o altar é separado "fisicamente" da assembleia celebrante ${ }^{6}$ mas simbolicamente unido a ela, na pessoa do celebrante principal ${ }^{7}$.

\footnotetext{
4 A palavra "presbitério" significa o "lugar do presbítero", isto é, de onde o sacerdote celebra os atos litúrgicos.

${ }^{5}$ Quer dizer, ofício, função.

${ }^{6}$ Das pessoas que estão celebrando a missa.

${ }^{7}$ Aquele que preside a missa, isto é, o bispo diocesano ou o sacerdote católico.
} 
O celebrante age in persona Christi $^{8}$, que representa o Cristo que celebra o seu mistério. Esta delimitação de espaços e funções revela a dimensão simbólica que está associada à hierarquia e a obediência ao mandato divino de "todas as vezes que o fizerem, fazei-o em minha memória" (Lucas 22,20). Desta feita, para celebrar o mistério, a Igreja se utiliza de símbolos e representações como mediação nos atos próprios do celebrante que são o altar, a cátedra, a mesa da palavra, o Círio Pascal, e a comunidade celebrante de fiéis.

Na figura 8 é apresentado o altar, construído em mármore italiano por ocasião da dedicação da Catedral à Santa Maria, Mãe de Deus. Os fiéis contam que no interior deste altar encontram-se as relíquias de vários santos. São fragmentos de ossos e amostras de hábito religioso destas pessoas que são grandes figuras para o catolicismo. Por fim, possui ao centro uma imagem cujo entalhamento se assemelha a um coração.

A figura 9 evoca uma antiga tradição segundo a qual o bispo diocesano é o autêntico sucessor dos apóstolos. Nas celebrações litúrgicas este religioso possui um lugar de destaque no presbitério, e costuma sentar-se em sua cátedra episcopal, uma cadeira imóvel, situada no altar-mor da Catedral, um símbolo do poder temporal e espiritual deste chefe da diocese.

Na figura 10 a mesa da palavra apresenta o relato da ressurreição de Jesus, quando três mulheres, por primeiro, receberam o anúncio da ressurreição. O testemunho ocular destas figuras narrado nos evangelhos sustenta a fé naquilo que é celebrado até os dias atuais; é uma atualização daquilo que viram, ouviram e acreditaram (Marcos 16, 1-8; Lucas 24, 1-10; João 20, 1-10).

O suporte do Círio Pascal (que significa "grande vela") conforme figura 11, talhado em bronze, trás gravações de narrativas bíblicas de diversos momentos da vida de Jesus. Os coroinhas ensinam que este suporte que guarda a grande vela simboliza a presença de Jesus Ressuscitado, e é usado para lembrar aos fiéis o mistério da Páscoa, celebrado a cada liturgia. Eles explicam que esta vela permanece acesa no presbitério ao longo dos cinquenta dias em que a Igreja celebra a Páscoa, e depois desse período, ela só é acesa na liturgia de batismo.

Na figura 12, é apresentada a estalactite que, por sua vez, lança gotas de água sobre a pia batismal, na qual serão banhados aqueles que serão batizados. Os coroinhas explicam que a água simboliza a nova criatura, regenerada em Cristo. Pelo batismo, os novos filhos da Igreja são libertados da escravidão do pecado e da morte.

\footnotetext{
${ }^{8}$ Expressão latina que quer dizer "age na pessoa de Cristo", isto é, um “instrumento" pelo qual o Cristo age.
} 
Por fim, a pia batismal em forma de cruz, é expressão de fé compartilhada. Em seu interior possui quatorze degraus, divididas em dois blocos de sete. $\mathrm{Na}$ descida, visualizam-se os sete pecados capitais, enquanto na subida, os sete dons do Espirito Santo (figura 13).

O interlocutor explica que o cristão, ao ser batizado, é introduzido no mistério da paixão, morte e ressurreição de Jesus. Assim, aquele que será batizado adentra a pia batismal, descendo pelos degraus dos sete pecados capitais, que recorda a condição do jugo do pecado. Ao imergir nas águas, o novo cristão sobe pelos degraus dos sete dons do Espirito Santo, prefigurando que a partir deste momento, torna-se uma criatura nova, regenerada em Cristo.

Figura 8: O altar, talhado em mármore italiano

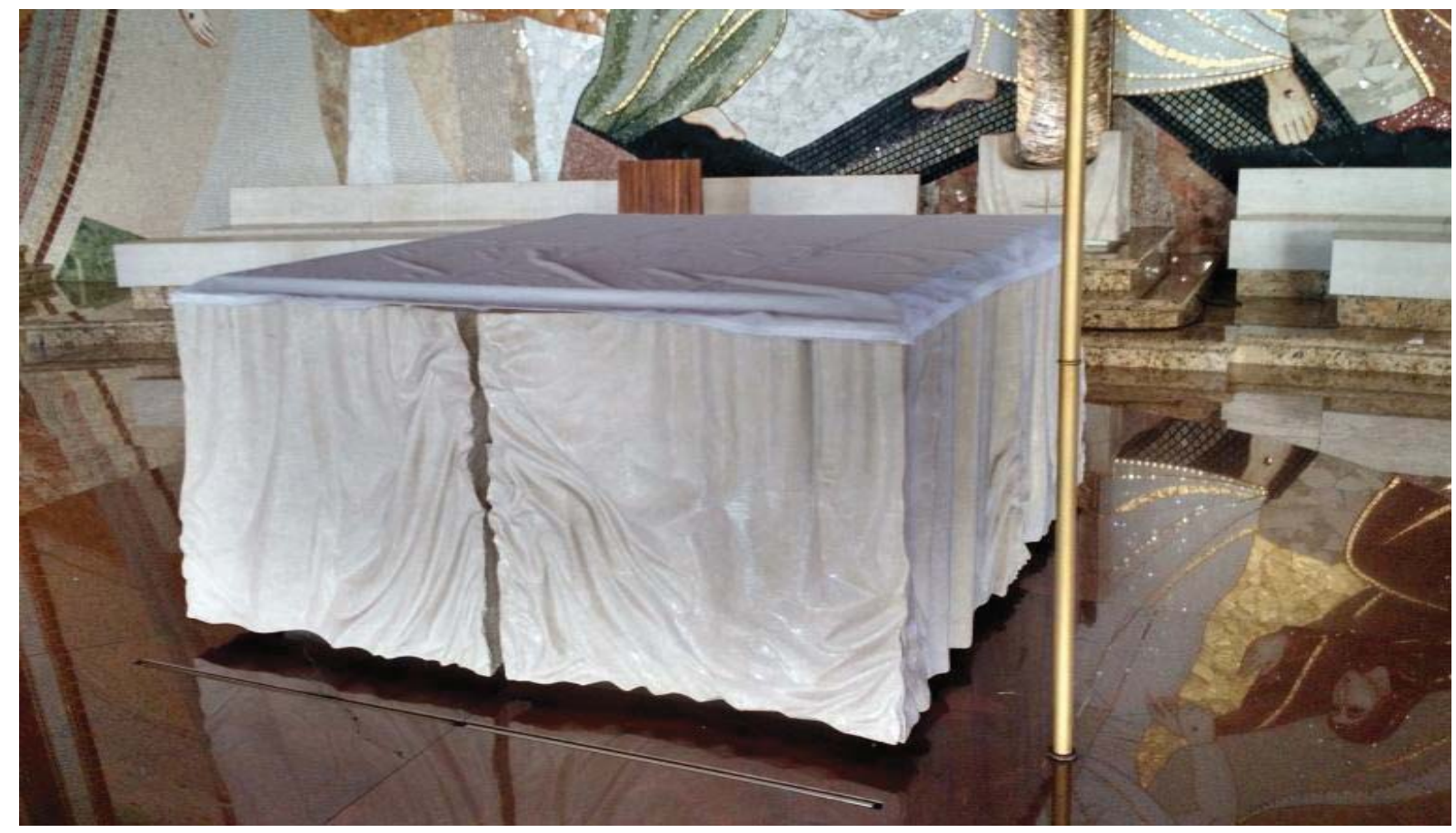

Fonte: Diocese de Castanhal, 2016 
Figura 9: A cátedra episcopal talhada em mármore branco italiano com encosto de bronze

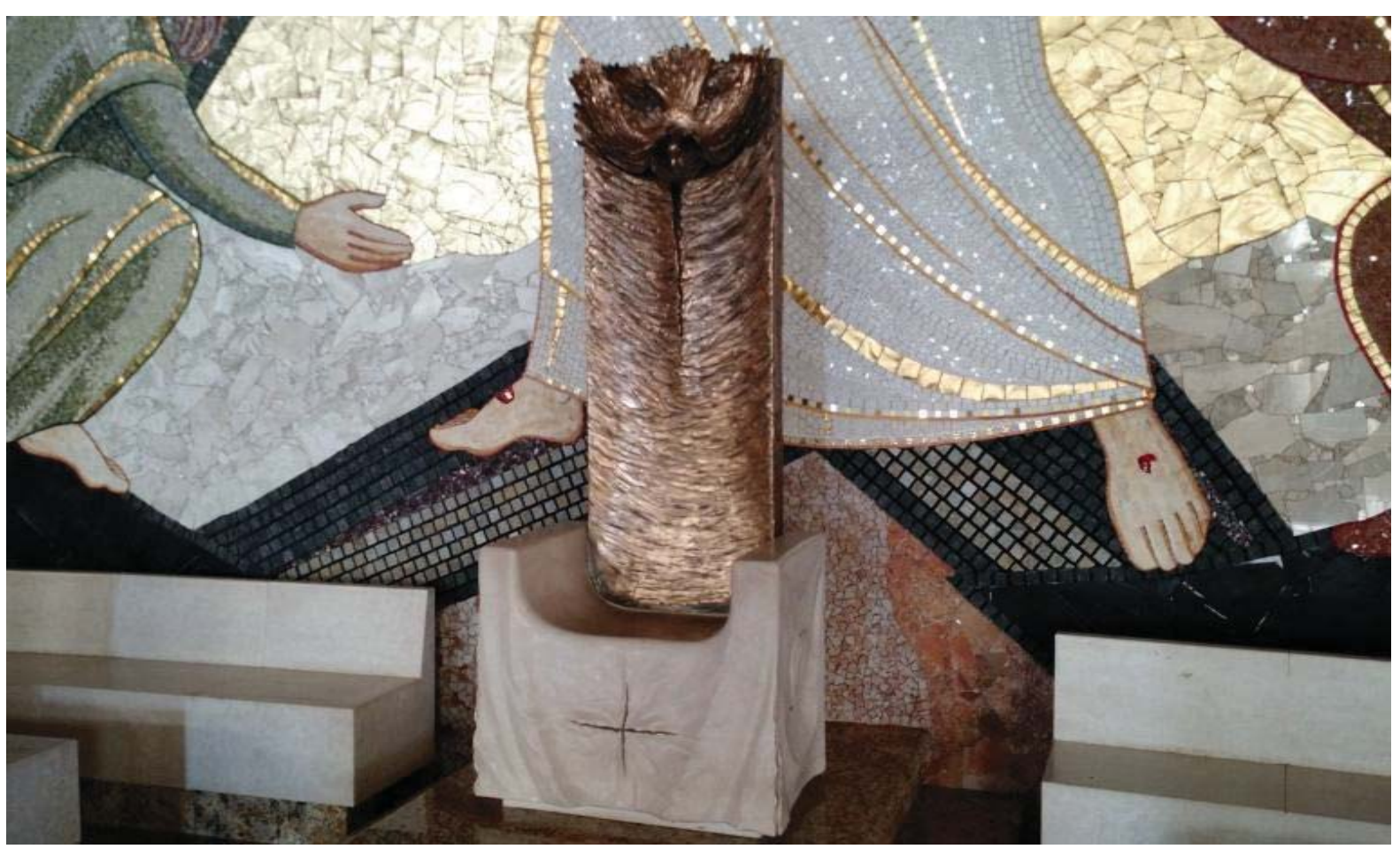

Fonte: Diocese de Castanhal, 2016

Figura 10: A mesa da palavra, Talhada em mármore branco italiano e retrata as testemunhas da Ressurreição

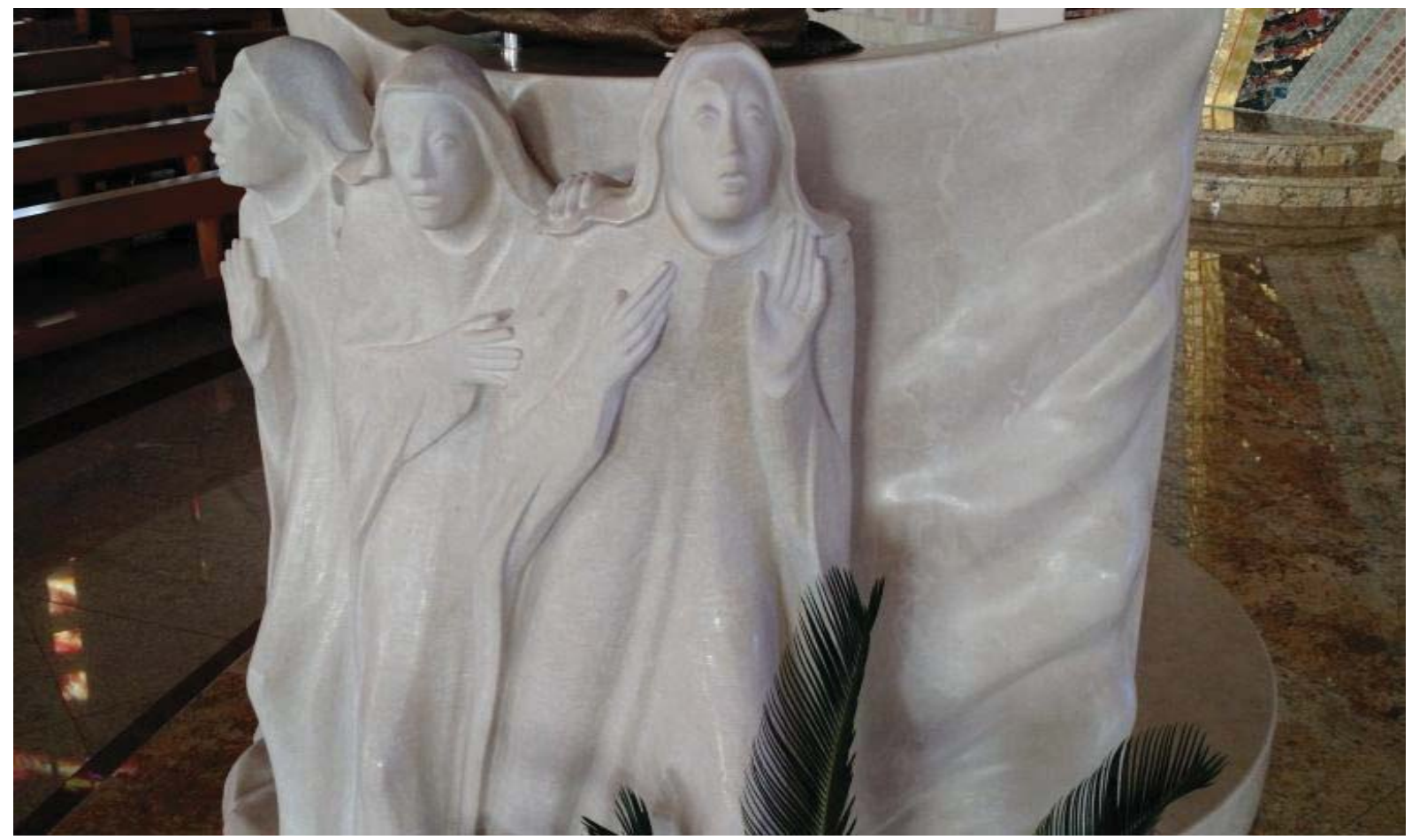

Fonte: Diocese de Castanhal, 2016 
Figura 11: O Círio da Via Lucis - passagens da vida de Jesus suporte do Círio Pascal entalhado em imagens de bronze que retratam cenas bíblicas

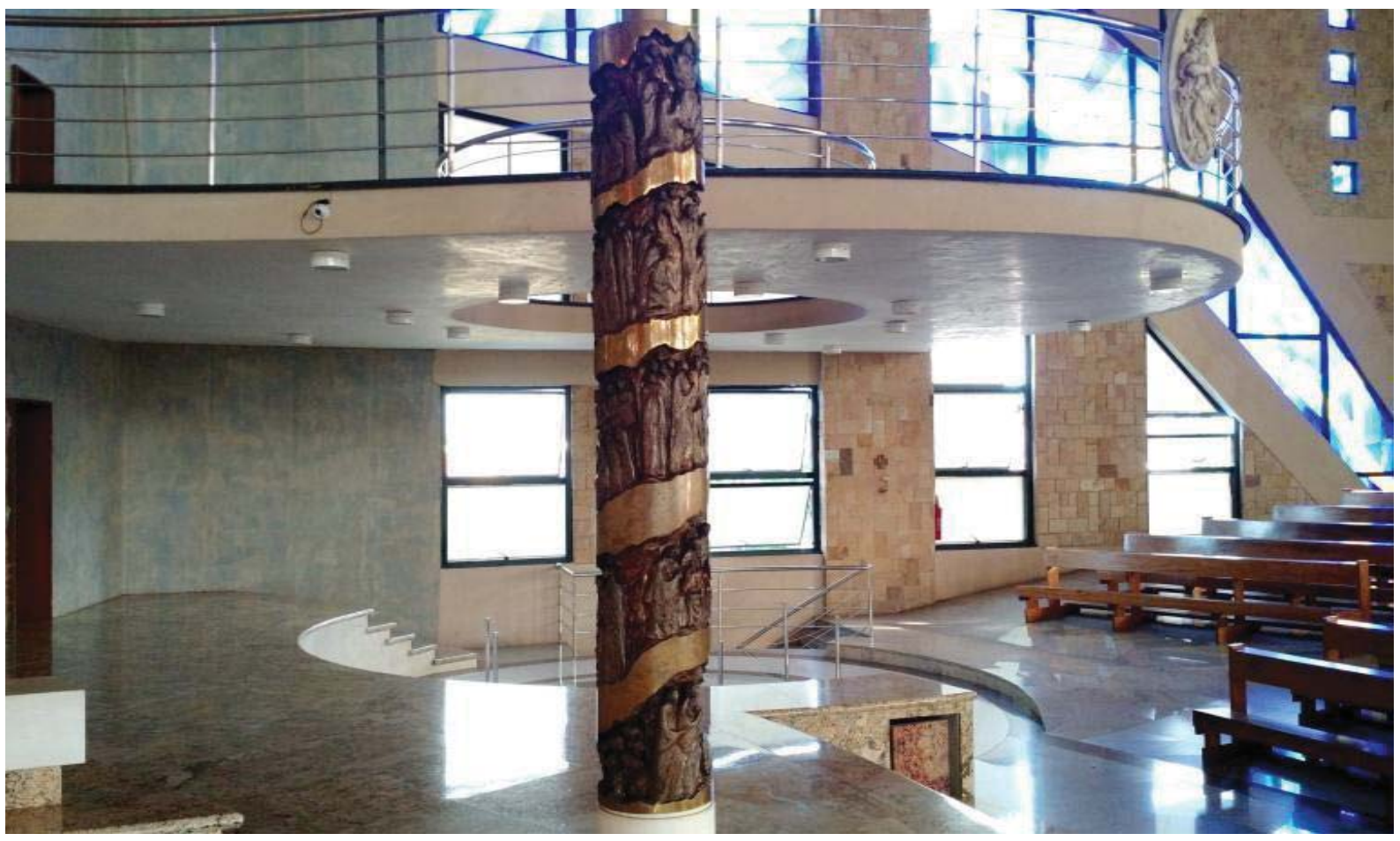

Fonte: Diocese de Castanhal, 2016

Figura 12: A estalactite posicionada sobre a pia batismal

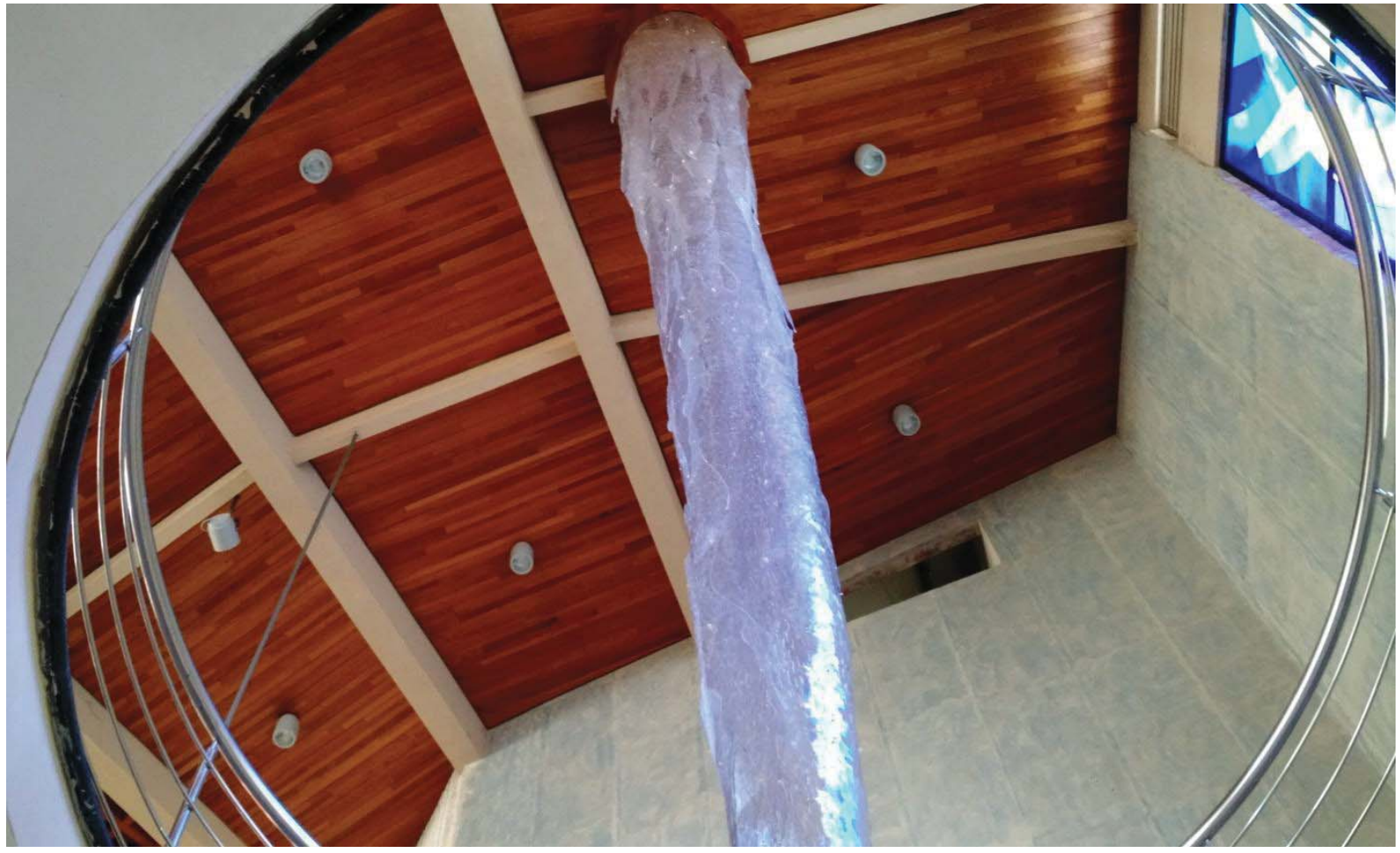

Fonte: Diocese de Castanhal, 2016 
Figura 13: Pia batismal em forma de cruz

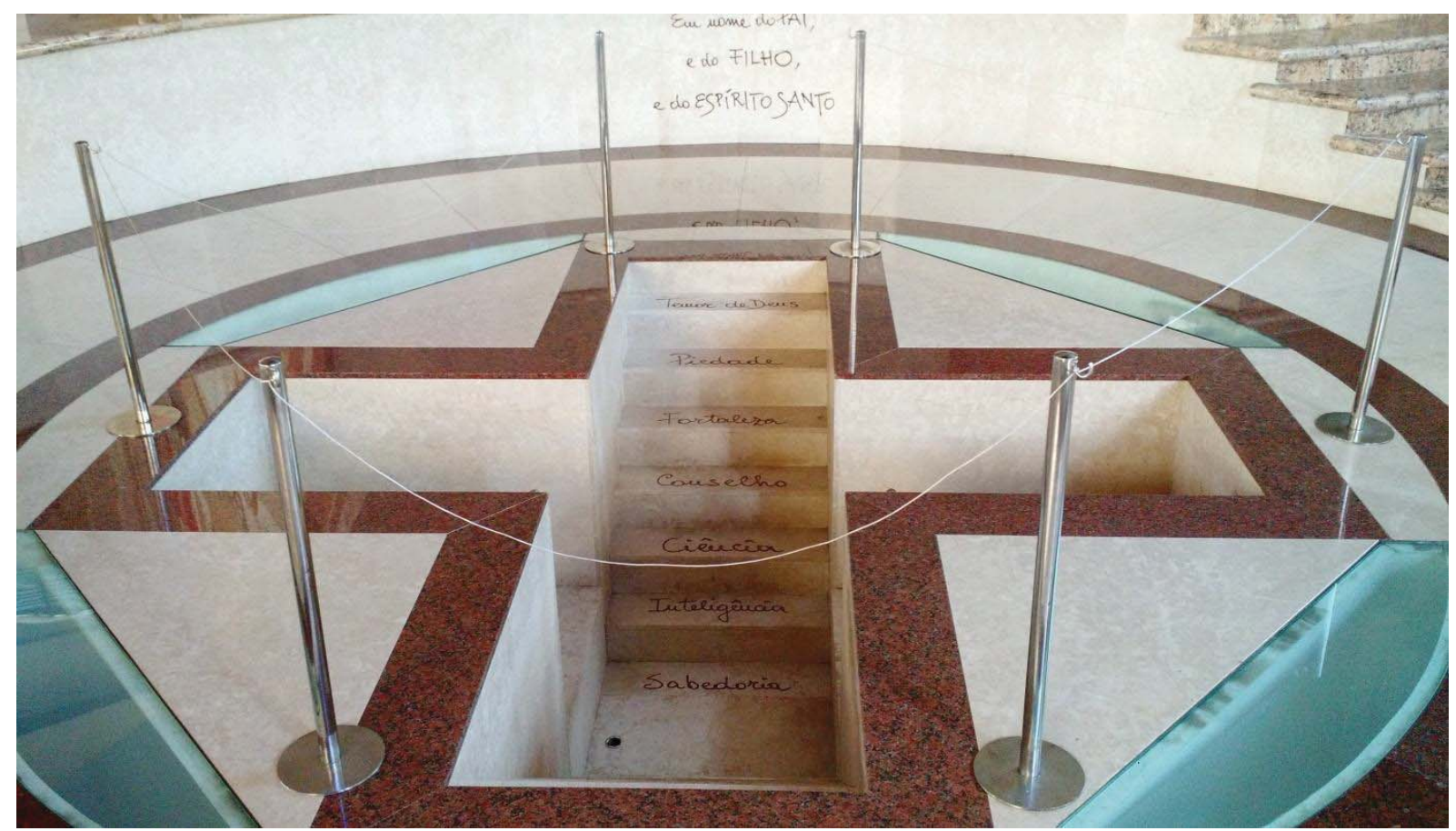

Fonte: Diocese de Castanhal, 2016

\section{ALGUMAS CONCLUSÕES}

A reflexão aqui esboçada é sustentada pela ideia de que as pessoas estabelecem uma rede de trocas sócio-religiosas com e a partir do uso das imagens, que por sua vez, ressignificam as experiências religiosas, e situam a discussão em duas linhas de abordagem: a que considera a imagem em sua finalidade evangelizadora por meio de representações e associações; e a que toma a imagem em caráter simbólico como possibilidade hermenêutica da experiência religiosa face ao seu caráter de interioridade. Essas duas linhas apresentam perspectivas convergentes e divergentes, em razão das diferentes formas de conhecimento e interioridade entre Ocidente e Oriente.

A intencionalidade evangelizadora das imagens é uma construção social do fenômeno religioso institucionalizado, ou seja, são paradigmas, formas simbólicas nas quais se estruturam as formas de vida religiosa no catolicismo contemporâneo, em que as referências são sempre necessárias, pois elas existem "para sintetizar o ethos de um povo - o tom, o caráter e a qualidade da sua vida, seu estilo e disposições morais e estéticos - e sua visão de mundo - o quadro que fazem do que são as coisas na sua simples atualidade, suas ideias mais abrangentes sobre ordem" (GEERTZ, 2008, p. 66). 
Desde a descoberta da consciência pela psicanálise, os estudos que se seguiram na história cultural mostram uma aproximação entre a "representação" e o "simbolismo" nos trabalhos de Burke (2005, p. 9) para quem os símbolos, “conscientes ou não, podem ser encontrados em todos os lugares [...] mas a abordagem do passado em termos de simbolismo, é apenas uma entre tantas" e igualmente em Morais (2015, p. 15) para quem a "história cultural está relacionada com as questões simbólicas e suas representações”.

O fato é que as duas percepções anteriormente sinalizadas lançam luzes e divergências no modo como a representação é mobilizada para "elucidar e ilustrar determinadas situações" (MORAIS, 2015, p. 10). Esta rediscussão ocorre particularmente com os estudos sobre o imaginário voltado a experiência religiosa, para quem a representação é problematizada em razão do seu caráter natural de "associação" pois compartilha de perspectivas modernistas ocidentais que negam o "símbolo invisível de uma história interna" (DURAND, 1979, p. $115)$.

\section{REFERÊNCIAS}

ARTOLA, Juan de Plazaola. Razón y sentido del arte Cristiano. Universidad de Deusto. Facultad de Teología. Cuadernos de Teología Deusto, Núm. 18. Bilbao, 1998.

BIBLE DE JÉRUSALEM. Études Biblique de Jérusalem. Les Éditions Du Cerf, Paris, 1998.

BURKE. Peter. O que é História Cultural. Tradução de Sérgio Goes de Paula. Rio de Janeiro: Jorge Zahar, 2005.

DUBY, Georges. O tempo das catedrais: a arte e a sociedade. Lisboa: Editora Estampa 1979.

DURAND, Gilbert. Science de l'homme e tradition, le "nouvel esprit anthropologique". Paris: Bordas, 1979.

FULCANELLI. O mistério das catedrais e a interpretação esotérica dos símbolos herméticos da grande obra. Lisboa: Editora dos 70, 1964.

GEERTZ, Clifford. A interpretação das culturas- 1.ed., IS.reimpr.- Rio de Janeiro: LTC, 2008.

JACQ, CHRISTIAN; BRUNIER, FRANÇOIS. El mensaje de los constructores de catedrales. [S.I.]:[S.ed.], 1974.

JAMESON, Fredric. Ensayos sobre el pós-modernismo. Traducido por Esther Pérez, Christian Ferrer y Sonia Marzo. Compilado por Horacio Tarcus. Libros Tauro, 1984. 
MORAIS, Aldilene Lopes de. Imagens de Sant'Ana: história, cultura e representação na Amazônia Paraense. Dissertação de Mestrado. Universidade Federal do Pará. Programa de Pós-Graduação em Linguagens e Saberes na Amazônia, PPLSA/UFPA, 2015. 